Click www.researchjournal.co.in/online/subdetail.html to purchase.

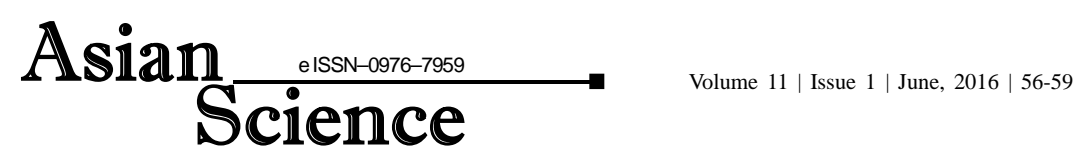

DOI : 10.15740/HAS/AS/11.1/56-59

Visit us | www.researchjournal.co.in

RESEARCH PAPER

\title{
Biofilm formation on food contact surfaces and its inhibition
}

\author{
ASHISH KUMAR*, PREETAM VERMA, SANDEEP KUMAR AND RAMENDRA SONI \\ Department of Molecular and Cellular Engineering, Jacob School of Biotechnology and Bioengineering, Sam Higginbottom \\ Institute of Agriculture Technology and Sciences, ALLAHABAD (U.P.) INDIA
}

\begin{abstract}
Almost all moist surfaces are colonized by microbial biofilms. Biofilms implicated in cross-contamination of food products and various human infections such as dental cavities. In this investigation three bacterial samples were used for biofilm formation in $48 \mathrm{hrs}$ in laboratory condition. Biofilms was determined by using spectrophotometric technique to overcome hazardous effect of biofilm on these biomaterials is suggested in this research. To subside the biofilms these parameters were used in the culture and after 24, 48, and $72 \mathrm{hrs} .0$ day has been taken at 450 for $S$. aureus and at 600 for both E. coli and Salmonella spp. The result was found that this chemical parameter showed antimicrobial activity and was capable to inhibit the biofilms formation. The preservatives were more effective acetic acid for maggi bottle, benzoic acid for pickle bottle and sodium sulphite for both fizz bottle and coke cane.
\end{abstract}

Key Words : Escherichia coli, Staphylococcus aureus, Salmonella spp. Biofilm, Food contact surfaces

View point paper : Kumar, Ashish, Verma, Preetam, Kumar, Sandeep and Soni, Ramendra (2016). Biofilm formation on food contact surfaces and its inhibition. Asian Sci., 11 (1): 56-59, DOI : 10.15740/HAS/AS/11.1/56-59.

\footnotetext{
* Author for correspondence

Ashish Kumar, Department of Molecular and Cellular Engineering, Jacob School of Biotechnology and Bioengineering, Sam Higginbottom Institute of Agriculture Technology and Sciences, ALLAHABAD (U.P.) INDIA (Email: ashish.biotech029@gmail.com)
} 